\title{
Rancangan Aplikasi Sistem Pendukung Keputusan (SPK) Pengangkatan Karyawan Menggunakan Metode Simple Additive Weighting (SAW) Pada PT. Ultra Prima Plast - Flexible Packaging
}

\author{
Dadang Amiruddin ${ }^{1}$, Ely Nuryani ${ }^{2}$, Hani Faturrohmah ${ }^{3}$ \\ Universitas Banten Jaya, Kota Serang - Banten \\ Email:dadang@capcx.com ${ }^{1)}$,elynuryani@unbaja.ac.id ${ }^{2}$, \\ faturrohmahhani@gmail.com ${ }^{3)}$
}

\begin{abstract}
PT. Ultra Prima Plast - Flexible Packaging always performs a trial period on every new employee. In appointment of new employee candidate required selection process and proper observation during the trial period to maximize the quality of the prospective employee, so far decision-making in the appointment of employees after the completion of the trial period is still done manually by using the assessment of several criteria. The criteria used from the assessment of employee performance are: absenteeism, quality of work, initiative, discipline, responsibility, communication ability and organizational skills. The purpose of holding research on PT. Ultra Prima Plast is to find out what problems or constraints exist in managing employee data, refining existing processes and getting new employee appointments using Simple Additive Weighting (SAW) method. As for data collection methods, the authors used literature study methods, field studies and interviews. In system development, writer use tool (model) of structured system modeling with design tool that is Diagram Unified Modeling Language (UML). Implementation and program design using PHP programming language and MYSQL database. Therefore the authors lift the title "Design Decision Support System (DSS) Application Employee Appointment Using Simple Additive Weighting Method (SAW) At PT. Ultra Prima Plast Flexible Packaging”.
\end{abstract}

Keywords: Decision Support Systems, Simple Additive Weighting (SAW)

\section{PENDAHULUAN}

Kemajuan bidang komputer memiliki dampak dalam bidang informasi. Saat ini informasi dibutuhkan baik di instansi pemerintahan maupun swasta. Dengan kebutuhan informasi tersebut maka dengan cara membenahi sistem pengolahan data dengan komputer agar memberikan kemudahan. Penggunaan 
informasi merupakan hal yang penting bagi setiap organisasi termasuk organisasi dalam sebuah perusahaan.

Pengelolaan sumber daya manusia (SDM) dari suatu perusahaan tentunya sangat mempengaruhi banyak aspek penentu keberhasilan kerja dari perusahaan. Oleh karena itu PT. Ultra Prima Plast - Flexible Packaging selalu melakukan masa percobaan (training) selama 3 bulan pada setiap karyawan yang baru masuk. Dalam pengangkatan calon karyawan baru dibutuhkan proses seleksi dan pengamatan yang tepat saat masa percobaan untuk memaksimalkan kualitas dari para calon karyawan tersebut, namun dalam era informasi dan teknologi yang semakin berkembang saat ini ternyata masih ada beberapa instansi dan perusahan yang dalam proses pengolahan datanya dengan menggunakan cara manual termasuk PT. Ultra Prima Plast - Flexible Packaging.

Dalam setiap mengambil keputusan mengenai hasil dari penilaian karyawanPT. Ultra Prima Plast - Flexible Packaging setelah selesai masa percobaan (training) tentunya butuh pemikiran yang matang berdasarkan kriteria-kriteria yang dibutuhkan dalam organisasi perusahaan. Kendala yang dihadapi adalah dalam mengambil suatu keputusan layak atau tidaknya calon karyawandiangkat sebagai karyawan diperusahaan tersebut, karena banyaknya calon karyawan yang harus diseleksi satu persatu berbagai kriteria - kriterianya untuk diangkat menjadi karyawansehingga dalam penentuan dari berbagai kriteria menyulitkan setiap departemen untuk menentukan karyawan yang selesai masa percobaan (training) layak atau tidak. Dengan mempertimbangkan hal tersebut maka diperlukan suatu sistem yang dapat berfungsi sebagai pendukung keputusan berdasarkan evaluasi selama masa percobaan sesuai kriteria-kriteria yang dibutuhkan pada perusahaan. Berdasarkan permasalahan tersebut maka di usulkan suatu aplikasi sistem penunjang keputusan di PT. Ultra Prima Plast - Flexible Packaging.

Oleh karena itu sesuai dengan deskripsi diatas, maka penelitianini membahas masalah tersebut dengan judul "Rancangan Aplikasi Sistem Pendukung Keputusan (SPK) Pengangkatan Karyawan Menggunakan 
Metode Simple Additive Weighting (SAW) Pada PT. Ultra Prima Plast Flexible Packaging“.

\section{Identifikasi Masalah}

1. Proses penilaian dan perhitungan kinerja masih dilakukan secara manual sehingga membutuhkan waktu yang lama.

2. Data penilaian kinerja untuk masing - masing pegawai masih disimpan dalam bentuk arsip/buku catatan pegawai, sehingga memungkinkan terjadinya kehilangan data

3. Mengalami kesulitan dalam proses pencarian data.

\section{Pembatasan Masalah}

Permasalahan yang akan dibahas dalam penelitianini yaitu tentang sistem penunjang keputusan pengangkatancalon karyawan menjadi karyawan kontrak yang dimulai dari penilaian kinerja karyawan selama masa percobaan (training) selama 3 bulan dan aplikasi yang dikembangkan adalah aplikasi web (tidak termasuk sistem keamanan).

\section{Perumusan Masalah}

1. Bagaimana agarproses penilaian dan perhitungan kinerja calon karyawanpadaPT. Ultra Prima Plast - Flexible Packagingdapat dilakukan secara otomatis sehingga lebih cepat?

2. Bagaimana cara meminimalisir kemungkinan hilangnya data penilaian kinerja calon karyawan pada PT. Ultra Prima Plast - Flexible Packaging?

3. Bagaimana agar proses pencarian data pada PT. Ultra Prima Plast dilakukan dengan mudah?

\section{METODOLOGI PENELITIAN}

\section{Metode Simple Additive Weighting (SAW)}

Menurut Kusumadewi (2007 : 64) "Metode SAW sering juga dikenal istilah metode penjumlahan berbobot. Konsep dasar metode SAW adalah mencari penjumlahan terbobot dari rating kinerja pada setiap alternatif pada 
semua atribut. "Sedangkan menurut Dicky Nofriansyah (2014:11-13), menjelaskan bahwa metode simple additive weighting sering juga dikenal dengan istilah metode penjumlahan terbobot. Konsep dasar metode simple additive weighting adalah mencari penjumlahan terbobot dari rating kinerja pada setiap alternatif pada semua atribut. Metode Simple additive weighting disarankan untuk menyelesaikan masalah penyeleksian dalam sistem pengambilan keputusan multi proses. Metode simple additive weighting merupakan metode yang banyak digunakan dalam pengambilan keputusan yang memiliki banyak atribut. Metode simple additive weightingmembutuhkan proses normalisasi matriks keputusan $(\mathrm{X})$ ke suatu skala yang didapat diperbandingkan dengan semua rating alternative yang ada. Formula untuk melakukan normalisasi tersebut adalah sebagai berikut:

Dimana dengan rij adalah rating kinerja ternormalisasi dari alternatif $\mathrm{Ai}$ pada atribut $\mathrm{Cj}: \mathrm{i}=1,2 \ldots, \mathrm{m}$ dan $\mathrm{j}=1,2 \ldots, \mathrm{n}$

$$
r_{i j} \begin{cases}\frac{X i j}{M a x X i j} & j i k a j \text { adalah atribut keuntungan (benefit) } \\ \frac{M i n X i j}{X i j} & j i k a j \text { adalah atribut biaya (cost) }\end{cases}
$$

Keterangan :

$\mathrm{r}_{i j}=$ Nilai rating ternormalisasi

$\operatorname{Max}_{i}=$ Nilai terbesar dari setiap kriteria i.

$\operatorname{Min}_{i}=$ Nilai terbesar dari setiap kriteria i.

$\mathrm{X}_{i j}=$ Nilai atribut yang dimiliki dari setiap kriteria.

Benefit $=$ Jika nilai terbesar adalah terbaik .

Cost $=$ Jika nilai terkecil adalah terbaik.

Nilai Preferensi untuk setiap alternatif $\left(\mathrm{V}_{i}\right)$ diberikan rumus sebagai berikut: 


$$
V_{i}=\sum_{j=1}^{n} w_{j} r_{i j}
$$

Keterangan :

$\mathrm{V}_{i}=$ Rangking untuk setiap alternatif.

$\mathrm{W}_{j}=$ Nilai bobot rangking (dari setiap kriteria).

$\mathrm{r}_{i j}=$ Nilai rating kinerja ternormalisasi.

Nilai $\mathrm{V} i$ yang lebih besar mengindikasikan bahwa alternatif $\mathrm{A}_{i}$ lebih terpilih.

\section{Langkah - Langkah Perhitungan Menggunakan Metode SAW}

Langkah Penyelesaian Metode Simple Additive Weighting (SAW), diantaranya :

1. Memberikan nilai setiap alternatif $\left(\mathrm{A}_{i}\right)$ pada setiap kriteria $\left(\mathrm{C}_{j}\right)$ yang sudah ditentukan,dimana nilai $i=\mathbf{1}, \mathbf{2}, \ldots \mathrm{m}$ dan $j=\mathbf{1}, \mathbf{2}, \ldots \mathrm{n}$

2. Memberikan nilai bobot (W) yang juga didapatkan berdasarkan nilai keanggotaan.

3. Melakukan normalisasi matriks dengan cara menghitung nilai rating kinerja ternormalisasi $\left(\mathrm{r}_{i j}\right)$ dari alternatif pada atribut $\mathrm{A}_{i}$ berdasarkan persamaan yang disesuaikan denganjenis atribut (atribut keuntungan / benefit $=$ MAKSIMUM atau atribut biaya $/$ cost =MINIMUM). Apabila berupa artibut keuntungan maka nilai keanggotaan $\left(\mathrm{X}_{i j}\right)$ dari setiapkolom atribut dibagi dengan nilai keanggotaan MAX (MAX ) dari tiap kolom, sedangkan untuk atribut biaya, nilai keanggotaan MIN (MIN $x_{i j}$ ) dari tiap kolom atribut dibagi dengan nilai keanggotaan $\left(x_{i j}\right)$ setiap kolom

4. Melakukan proses perangkingan untuk setiap alternatif $\left(\mathrm{V}_{i}\right)$ dengan cara mengalikan nilai bobot $\left(\mathrm{W}_{j}\right)$ dengan nilai rating kinerja ternormalisasi $\left(\mathrm{r}_{i j}\right)$.

\section{UnifiedModellingLanguage (UML)}

Menurut Rosa A.S, M. Shalahudin, (2015 : 133), “Unified Modelling Language (UML ) adalah salah satu standar bahasa yang banyak digunakan 
di dunia industri untuk mendefinisikan requirement, membuat analisis dan desain, serta menggambarkan arsitektur dalam pemrograman berorientasi objek."Adapun tujuan atau fungsi dari penggunaan UML, adalah sebagai berikut :

a. Dapat memberikan bahasa permodelan visual kepada pengguna dari berbagai macam pemerograman maupun proses rekayasa.

b. Dapat menyatukan praktek-praktek terbaik yang ada dalam permodelan.

c. Dapat memberikan model yang siap untuk digunakan, merupakan bahasa permodelan visual yang ekspresif untuk mengembangkan sistem dan untuk saling menukar model secara mudah.

d. Dapat berguna sebagai blue print, sebab sangat lengkap dan detail dalam perancangannya yang nantinya akan diketahui informasi yang detail mengenai koding suatu program.

e. Dapat memodelkan sistem yang berkonsep berorientasi objek, jadi tidak hanya digunakan untuk memodelkan perangkat lunak (software) saja.

f. Dapat menciptakan suatu bahasa permodelan yang nantinya dapat dipergunakan oleh manusia maupun oleh mesin.

Jenis-Jenis Diagram UML (Unified Modelling Language) dan Beberapa Contoh Diagramnya

Adapun beberapa jenis diagram UML (Unified Modelling Language) menurut Sucipto (2011:197) adalah sebagai berikut :

\section{a. Use case diagram}

Use case diagram yaitu salah satu jenis diagram pada UML yang menggambarkan interaksi antara sistem dan aktor.Use case diagram juga dapat mendeskripsikan tipe interaksi antara si pemakai sistem dengan sistemnya. 
Jurnal Sistem Informasi dan Informatika (SIMIKA)

Vol.1 No.1 tahun 2018



Gambar 1 Use case diagram

\section{b. Activity Diagram}

Activity diagram atau diagram aktivitas yaitu salah satu jenis diagram pada UML yang dapat memodelkan proses-proses apa saja yang terjadi pada sistem.



Gambar 2 Activity Diagram 


\section{c. Sequence diagram}

Sequence diagram yaitu salah satu jenis diagram pada UML yang menjelaskan interaksi objek yang berdasarkan urutan waktu. Sequence diagram juga dapat menggambarkan urutan atau tahapan yang harus dilakukan untuk dapat menghasilkan sesuatu seperti pada use case diagram.



\section{Gambar 3 Sequence diagram}

\section{d. Class diagram}

Class diagram yaitu salah satu jenis diagram pada UML yang digunakan untuk menampilkan kelas-kelas maupun paket-paket yang ada pada suatu sistem yang nantinya akan digunakan. Jadi diagram ini dapat memberikan sebuah gambaran mengenai sistem maupun relasi-relasi yang terdapat pada sistem tersebut. 
Jurnal Sistem Informasi dan Informatika (SIMIKA)

Vol.1 No.1 tahun 2018

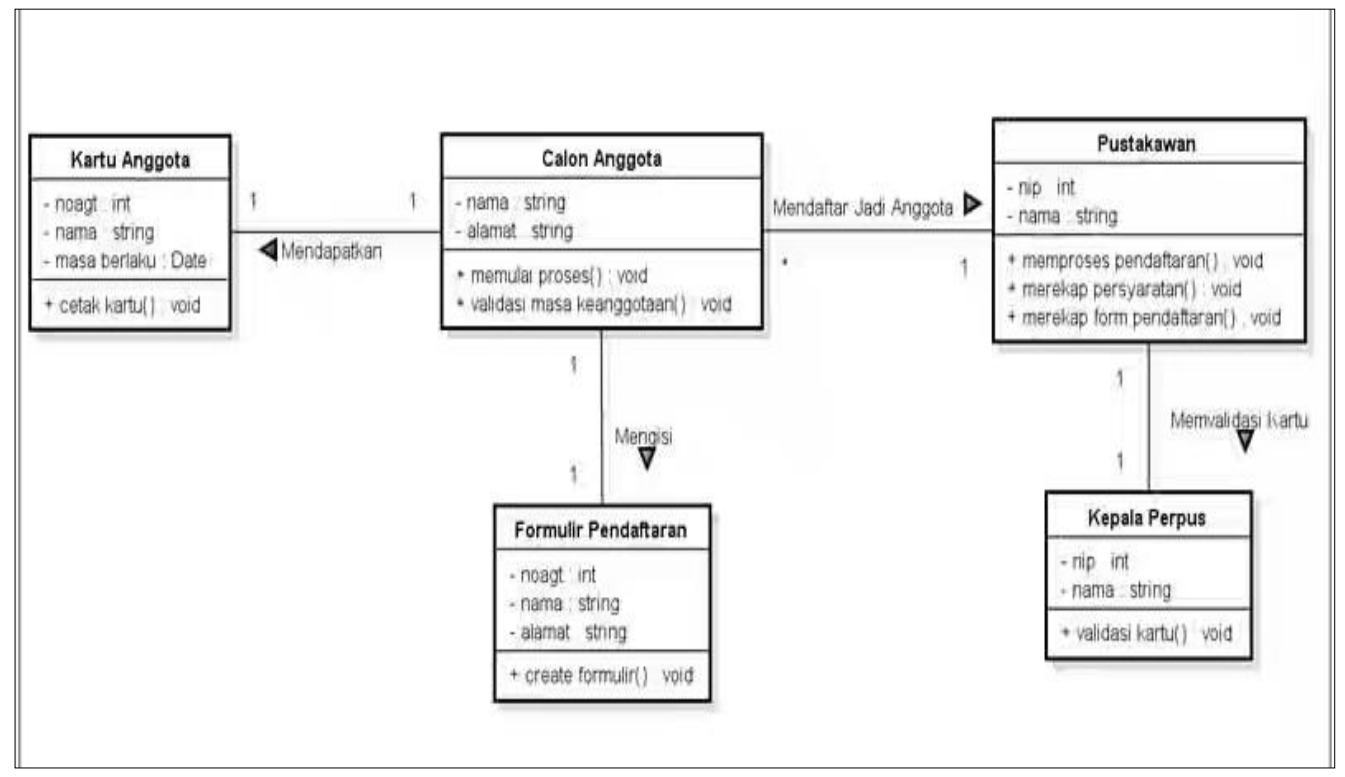

Gambar 4 Class diagram

\section{e. Statemachine diagram}

Statemachine diagram yaitu salah satu jenis diagram pada UML yang menggambarkan transisi maupun perubahan keadaan suatu objek pada sistem.

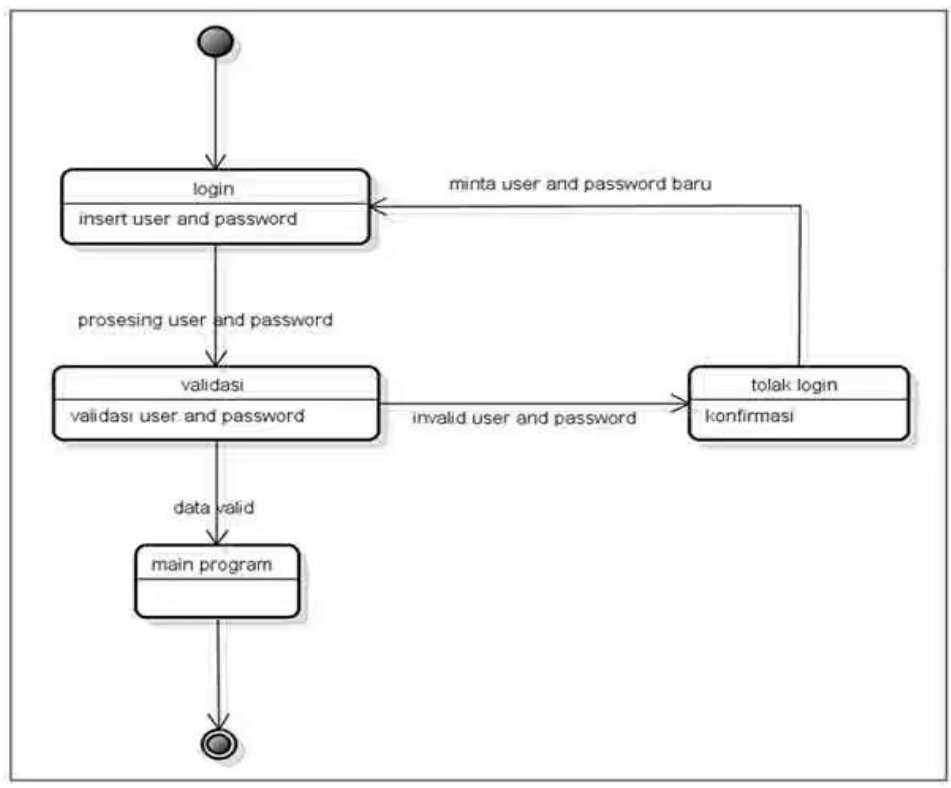

\section{Gambar 5 Statemachine diagram}

\section{f. Communication diagram}

Communication diagram yaitu salah satu jenis diagram pada UML yang dapat menggamabarkan tahapan terjadinya suatu aktivitas dan diagram ini juga menggambarkan interaksi antara objek yang ada pada 
sistem. Hampir sama seperti sequence diagram akan tetapi communication diagram lebih menekankan kepada peranan masing-masing objek pada sistem.

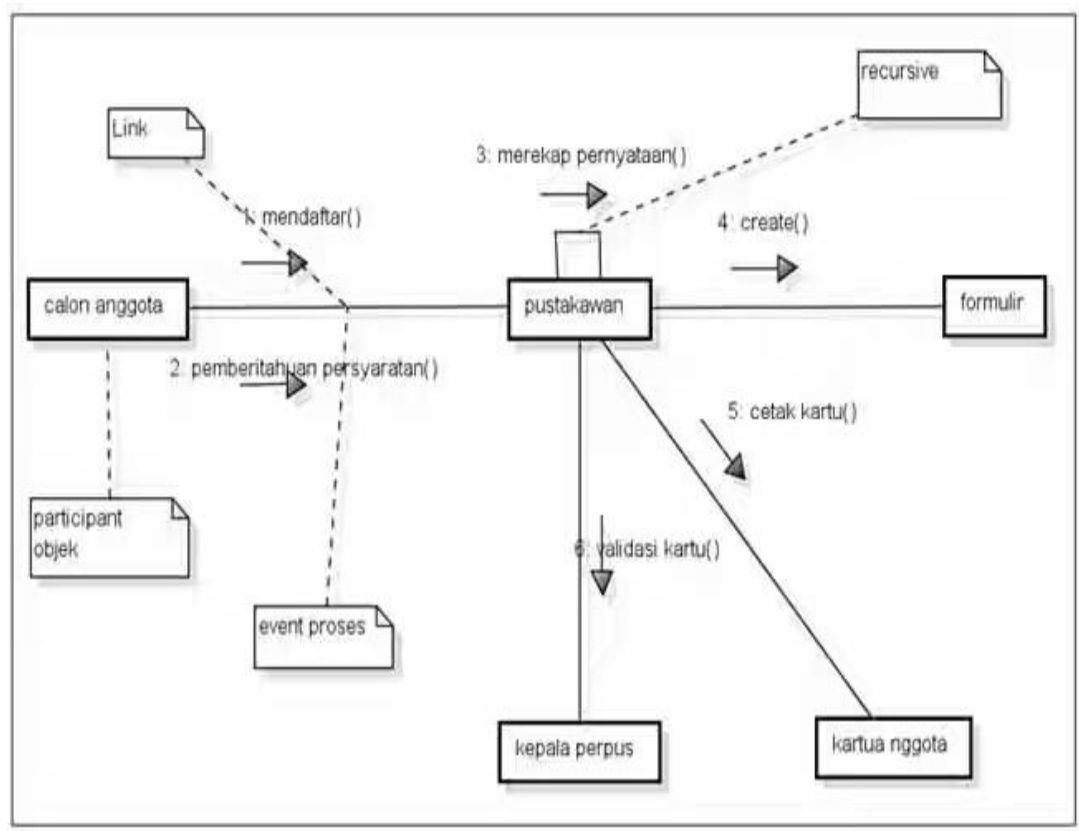

Gambar 6 Communication diagram

\section{g. Deployment diagram}

Deployment diagram yaitu salah satu diagram pada UML yang menunjukan tata letak suatu sistem secara fisik, dapat juga dikatakan untuk menampilkan bagian-bagian softwere yang terdapat pada hardwere dan digunakan untuk menerapkan suatu sistem dan hubungan antara komponen hardwere. Jadi deployment diagram intinya untuk menunjuk

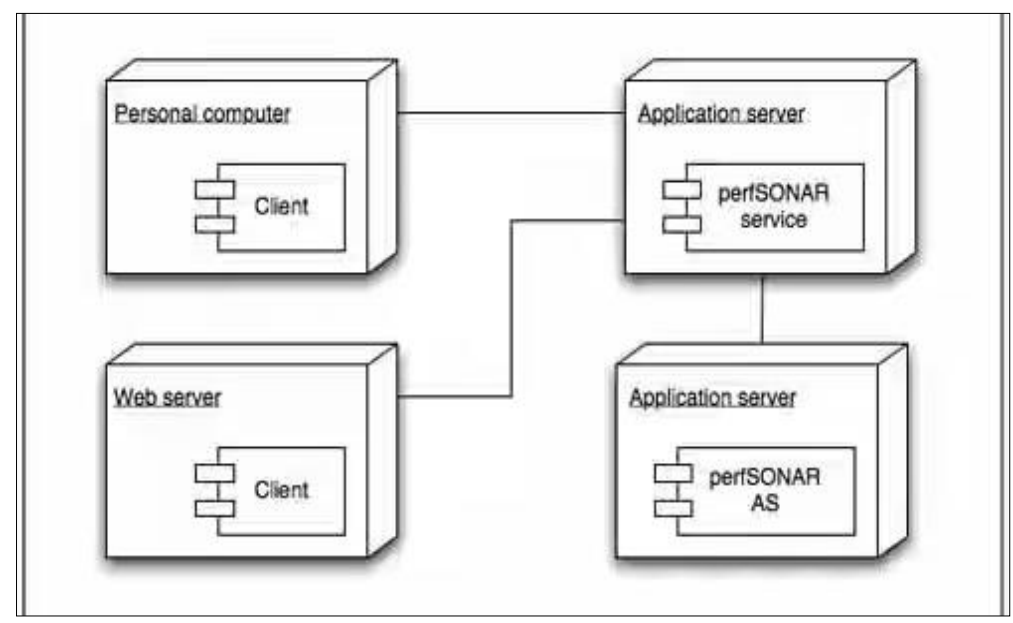

Gambar 7 Deployment diagram 


\section{LITERATURE REVIEW}

Beberapa penelitian sebelumnya (literature review) telah dilakukan yang berkaitan dengan sistem pendukung keputusan dengan metode simple additive weighting $(S A W)$. Sebagai acuan, pertimbangan, dan perbandingan, serta untuk memperkuat hasil penelitian ini maka dilakukan identifikasi terkait sistem serta metode yang pernah dilakukan, pada penelitian sebelumnya yang memiliki korelasi yang sesuai yaitu sistem pendukung keputusan dengan metode simple additive weighting $(S A W)$. Beberapa literature review yang didapatkan diantaranya dibahas pada alinea-alinea berikutnya.

Penelitian yang dilakukan oleh Pristiwanto , 2014, "Sistem pendukung keputusan dengan metode simple additive weighting (SAW) untuk menentukan dosen pembimbing skripsi”. Ada Empat kriteria penilaian yang digunakan digunakan dalam penelitian ini yakni (1) pendidikan, (2) status, (3) bidang keahlian, (4) golongan. Menunjukkan bahwa hasil perhitungan dari sistem telah sesuai dengan hasil perhitungan secara manual. Dapat dijadikan tolak ukur oleh perguruan tinggi dalam menentukan dosen pembimbing. Belum bisa membaca data metah dosen yang akan menjadi pembimbing.belum dibangun secara mecari dan belum berbasis WEB.

Penelitian yang dilakukanoleh S.M Santi Winarsih, 2010 yang berjudul "Rancang Bangun Sistem Pendukung Keputusan Untuk Pemilihan Bayi Sehat". Penelitian ini dilakukan untuk mengetahui prosedur penilaian dan pemilihan bayi sehat yang dilakukan oleh petugas kesehatan untuk menghasilkan Sistem Pendukung Keputusan Untuk Pemilihan Bayi Sehat berdasarkan kiteria yang telah ditetapkan. Dalam menentukan bayi sehat, sistem menggunakan metode pembobotan nilai dengan kriteria - kriteria yang telah ditetapkan yaitu data bayi, penilaian ibu, perilaku sehat, pemeriksaan fisik dan pemeriksaan gigi.

Penelitian selanjutnya dilakukan oleh Gerdon, 2011 yang berjudul "Sistem Pendukung Keputusan Untuk Menentukan Penerimaan Beasiswa Bagi Mahasiswa". Penelitian ini dilakukan untuk membantu pemilihan mahasiswa yang layak mendapatkan beasiswa di Perguruan Tinggi 
berdasarkan kriteria yang telah ditentukan. Dalam menentukan penerimaan beasiswa, sistem menggunakan metode Simple Additive Weighting (SAW) dengan kriteria - kriteria yaitu nilai IPK, penghasilan orang tua, semester, jumlah tanggungan orang tua, danusia.

Selanjutnya Penelitian yang dilakukanoleh Rosario Agustina Lumbangaol, 2013, “Sistem Pendukung Keputusan Penanganan Gizi Buruk Pada Balita Menggunakan Metode Fuzzy Mamdani”. Ada Empat indikator penilaian yang digunakan dalam penelitian ini yaitu umur balita, berat badan balita, tinggi balita dan nilai gizi balita. Penelitian ini bertujuan untuk membangun sebuah sistem yang dapat lebih mudah memantau tumbuh kembang balita dan untuk mempermudah pengambilan keputusan penanganan gizi buruk balita.

Penelitian terakhir dilakukan oleh Ali Wahyu Oktaputra dan Edi Noersasongko, 2014, "Sistem Pendukung Keputusan Kelayakan Pemberian Kredit Motor Menggunakan Metode Simple Additive Weighting Pada Perusahaan Leasing HD Finance". Penelitian ini dilakukan untuk mengurangi satu kendala pendapatan perusahaan yang berkurang yang diakibatkan kredit macet. Oleh karena itu perlu adanya suatu Sistem Pendukung Keputusan yang mampu menganalisa konsumen yang layak mendapat kredit atau tidak. Adapun kriteria yang digunakan sebagai indikator penilaian adalah Character (kepribadian), Capital (uangmuka), Capacity (kemampuan), Collateral (jaminan), Condition (kondisi).

Dari kelima literature review yang ada, telah banyak penelitian mengenai sistem pendukung keputusan baik dengan metode Simple Additive Weighting (SAW) ataupun metode yang lain. Namun dapat disimpulkan pula bahwa belum ada penelitian yang secara khusus membahas mengenai Sistem Pendukung Keputusan (SPK) Pengangkatan Karyawan Menggunakan Metode Simple Additive Weighting (SAW), sehingga dalam penelitian ini SPK dibuat khusus untuk menentukan pengangkatan karyawan dari karyawan training menjadi karyawan tetap yang layak sesuai dengan kriteria pengangkatan karyawan tetap pada PT. Ultra Prima Plast - Flexible Packaging. 


\section{PEMBAHASAN}

\section{UML Diagram}

\section{Use Case Diagram}

Dalam Use Case Diagram, ada beberapa aktor yang terlibat dalam sistem. Diantaranya adalah HRD, Dept Manager dan Section Manager.

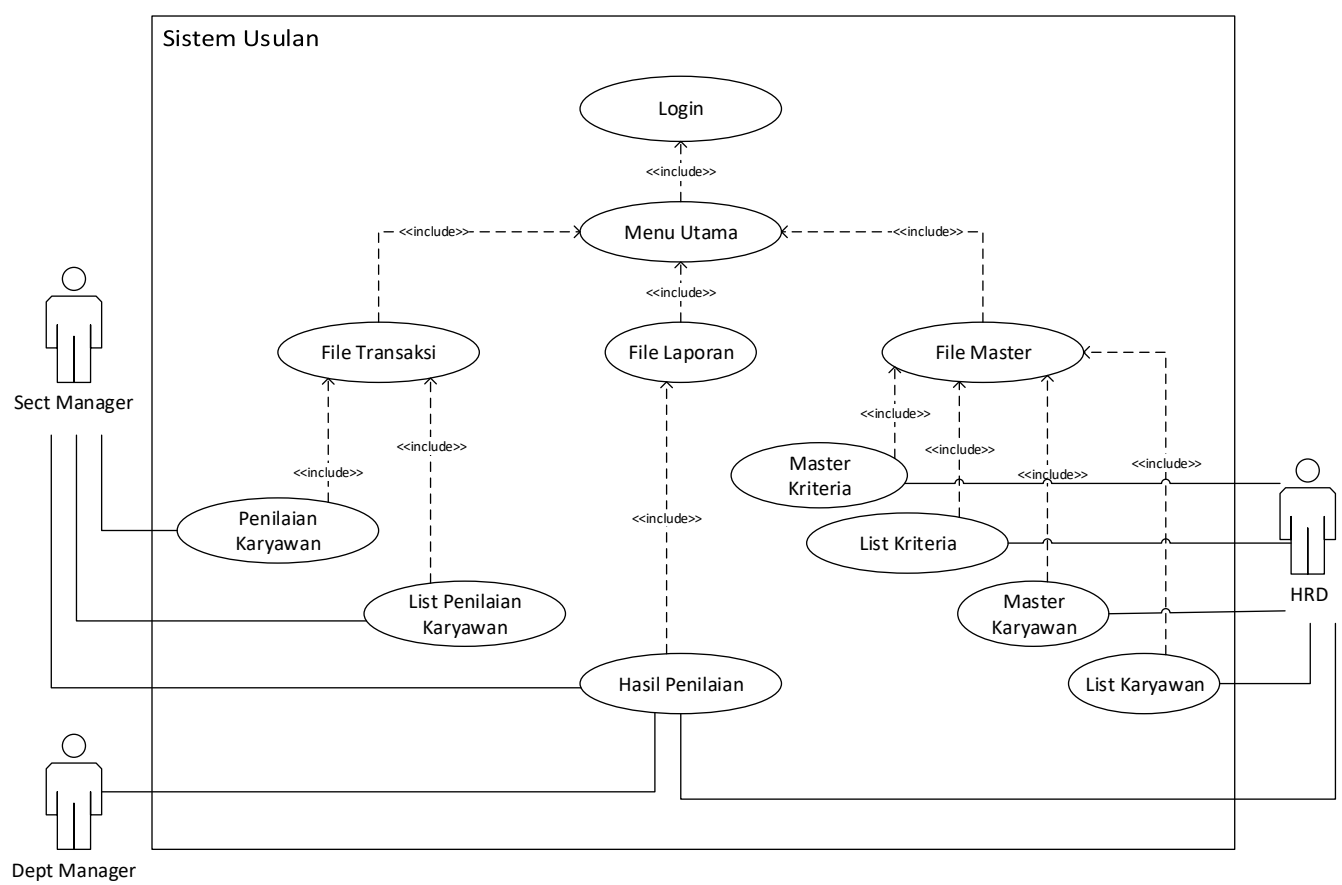

Gambar 8 Use Case Diagram Sistem Usulan

Tabel 1

Deskripsi Aktor dalam Usecase

\begin{tabular}{|l|l|l|l|}
\hline No & Aktor & \multicolumn{3}{|c|}{ Deskripsi } \\
\hline 1 & $\begin{array}{l}\text { Sect } \\
\text { Manager }\end{array}$ & $\begin{array}{l}\text { Aktor yang bertugas untuk menilai karyawan dan } \\
\text { menghitung berdasarkan Sistem penunjang keputusan. }\end{array}$ \\
\hline 2 & $\begin{array}{l}\text { Dept } \\
\text { Manager }\end{array}$ & $\begin{array}{l}\text { Bertanggung jawab atas semua data penilaian karyawan } \\
\text { yang dilakukan oleh Sect Manager yang diberikan } \\
\text { selama masa percobaan kerja dan bertugas untuk } \\
\text { mengevaluasi hasil Penilaian sebagai bahan } \\
\text { pengambilan keputusan dan menyetujui hasil } \\
\text { keputusan. }\end{array}$ \\
\hline
\end{tabular}




\begin{tabular}{|l|l|l|}
\hline 3 & HRD & $\begin{array}{l}\text { Aktor yang bertugas sebagai admin yang mengelola } \\
\text { data-data karyawan yang sedang dalam masa percobaan } \\
\text { dan data-data kriteria penilaian. }\end{array}$ \\
\hline
\end{tabular}

Tabel 2

Deskripsi Usecase

\begin{tabular}{|c|c|c|}
\hline No & Usecase & Deskripsi \\
\hline 1 & Login & Memvalidasi user yang masuk ke dalam system \\
\hline 2 & $\begin{array}{l}\text { Halaman } \\
\text { Utama }\end{array}$ & $\begin{array}{l}\text { Merupakan tampilan halaman ketika user masuk ke } \\
\text { dalam sistem aplikasi setelah berhasil login. Di dalam } \\
\text { tampilan ini terdapat beberapa menu untuk user }\end{array}$ \\
\hline 3 & $\begin{array}{l}\text { Master } \\
\text { Kriteria }\end{array}$ & $\begin{array}{l}\text { Menu untuk mengimput data kriteria yang dibutuhkan } \\
\text { perusahaan }\end{array}$ \\
\hline 4 & List Kriteria & $\begin{array}{l}\text { Menu yang di dalamnya terdapat fungsi untuk } \\
\text { mengubah dan mengurangi data kriteria penilaian } \\
\text { sesuai kriteria yang ditetapkan. Menu ini dikelola oleh } \\
\text { bagian HRD. }\end{array}$ \\
\hline 5 & $\begin{array}{l}\text { Master } \\
\text { Karyawan }\end{array}$ & Menu untuk memasukkan data karyawan \\
\hline 6 & $\begin{array}{l}\text { List } \\
\text { Karyawan }\end{array}$ & $\begin{array}{l}\text { Menu yang di dalamnya terdapat fungsi untuk } \\
\text { mengubah, menambah dan mengurangi data } \\
\text { karyawan. }\end{array}$ \\
\hline 7 & $\begin{array}{l}\text { Penilaian } \\
\text { Karyawan }\end{array}$ & $\begin{array}{l}\text { Menu untuk memasukkan data penilaian kriteria pada } \\
\text { setiap kriteria }\end{array}$ \\
\hline 8 & $\begin{array}{l}\text { List } \\
\text { Penilaian } \\
\text { Karyawan }\end{array}$ & $\begin{array}{l}\text { Menu yang } \\
\text { didalamnyaterdapatfungsiuntukmengubahdanmenghap } \\
\text { us data penilaiankriteria }\end{array}$ \\
\hline 9 & $\begin{array}{l}\text { Laporan } \\
\text { Hasil } \\
\text { Penilaian }\end{array}$ & $\begin{array}{l}\text { Menu untuk menampilkan hasil penilaian kinerja } \\
\text { karyawan }\end{array}$ \\
\hline
\end{tabular}




\section{Activity Diagram}

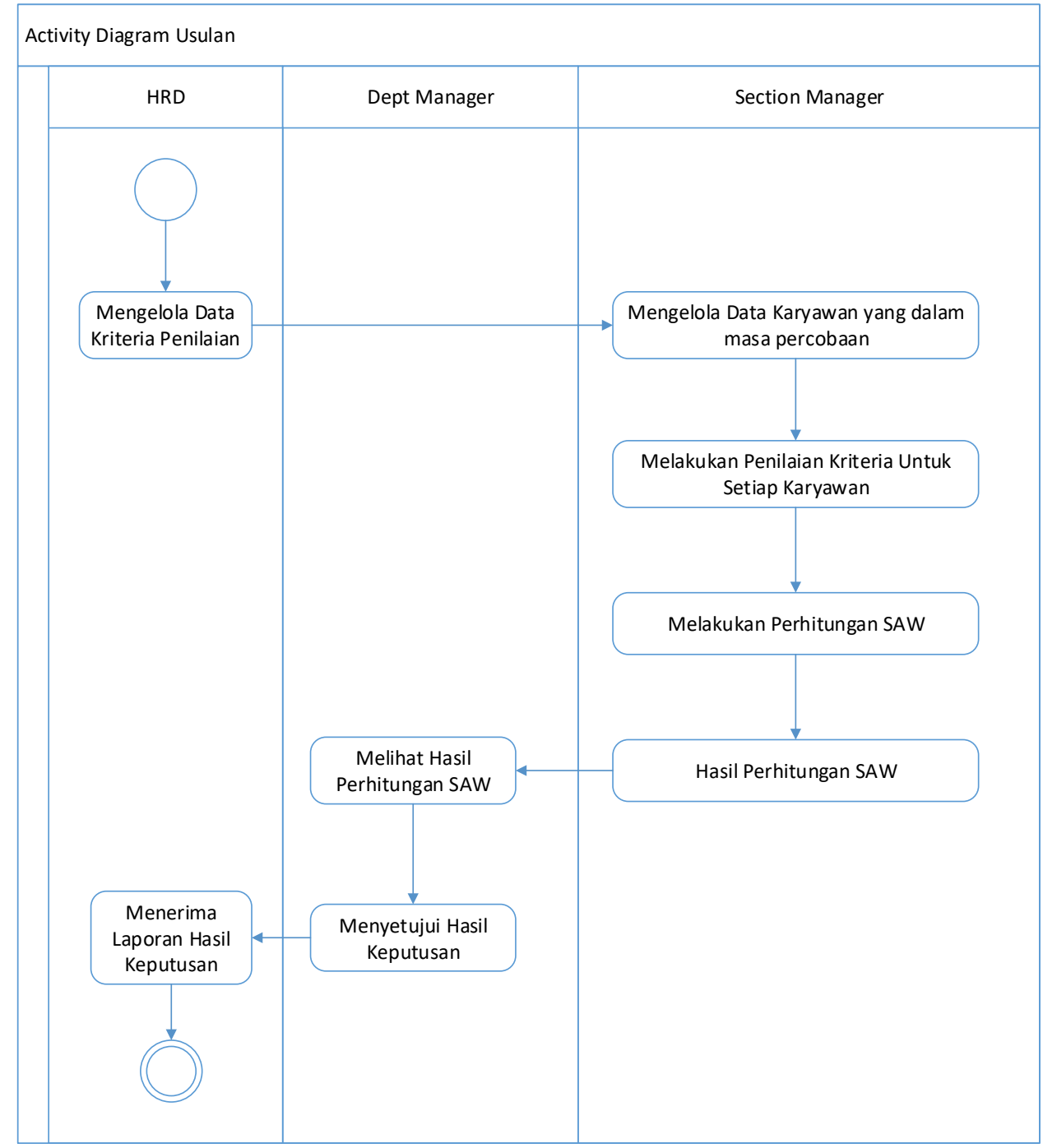

Gambar 9 Activity Diagram Sistem Usulan

Berdasarkan activity diagram pada gambar diatas, adapun uraian kerjanya adalah sebagai berikut:

a. Administrator akan mengelola data login user untuk kemudian digunakan oleh user.

b. HRD mengelola data kriteria penilaian yang sudah ditetapkan oleh perusahaan.

c. Section Manager memasukkan data penilaian berdasarkan nama karyawan dan kriteria yang sudah ditetapkan oleh perusahaan dan juga berdasarkan hasil pengamatan kinerja karyawan. 
d. Semua data karyawan yang sudah diberikan penilaian dieksekusi berdasarkan kriteria dan dihitung berdasarkan perhitungan SAW

e. Departemen Manager melihat hasil penilaian untuk pengambilan keputusan dan berdasarkan data tersebut, hasilnya akan ditinjau ulang, apabila ada hasil yang tidak sesuai maka Dept Manager akan menginformasikan kepada Sect Manager untuk merevisi data penilaian.

f. HRD menerima laporan hasil keputusan dari pimpinan departemen yang bersangkutan

\section{Class Diagram}

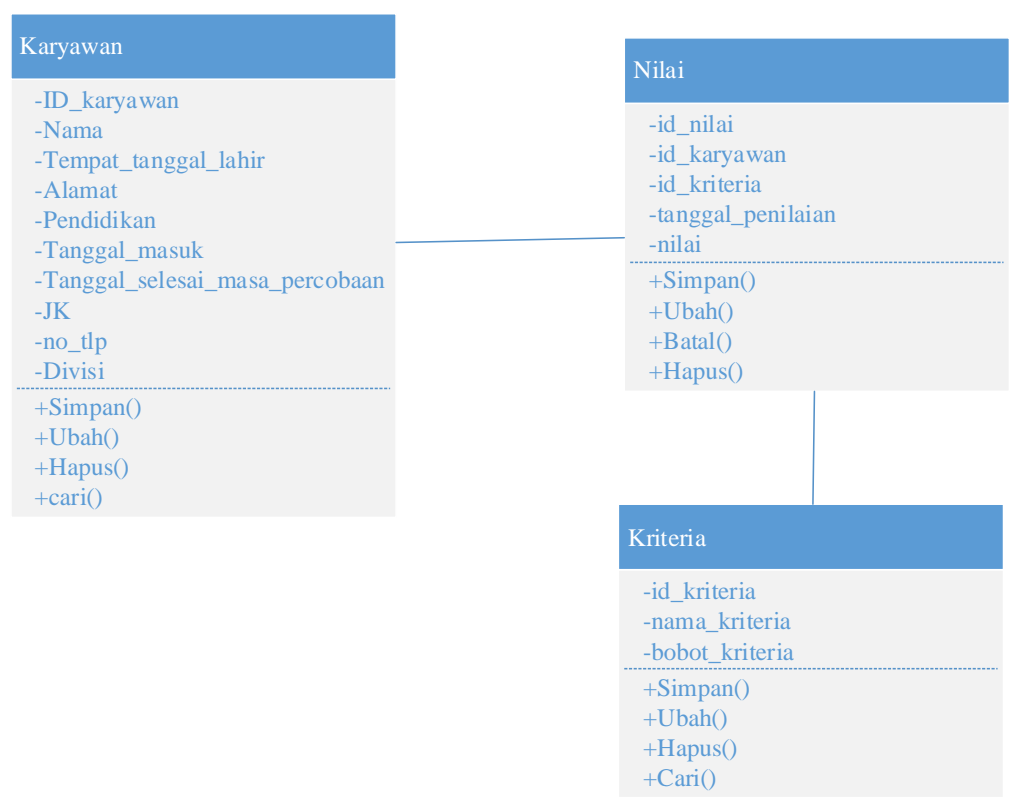

Gambar 10 Class Diagram Sistem Usulan

Tabel 3

Deskripsi Class Diagram Sistem Usulan

\begin{tabular}{|l|l|l|}
\hline NO & \multicolumn{1}{|c|}{ Nama Tabel } & \multicolumn{1}{|c|}{ Deskripsi } \\
\hline 1 & Karyawan & $\begin{array}{l}\text { Berisi data-data karyawan seperti id karyawan, } \\
\text { nama karyawan, jenis kelamin, dll. }\end{array}$ \\
\hline 2 & Nilai & $\begin{array}{l}\text { Merupakan data hasil perhitungan SAW } \\
\text { karyawan }\end{array}$ \\
\hline 3 & Kriteria & Berisi data kriteria dan nilai prioritas kriteria \\
\hline
\end{tabular}




\section{Struktur Tampilan}



Gambar 11 Struktur Tampilan Menu HRD

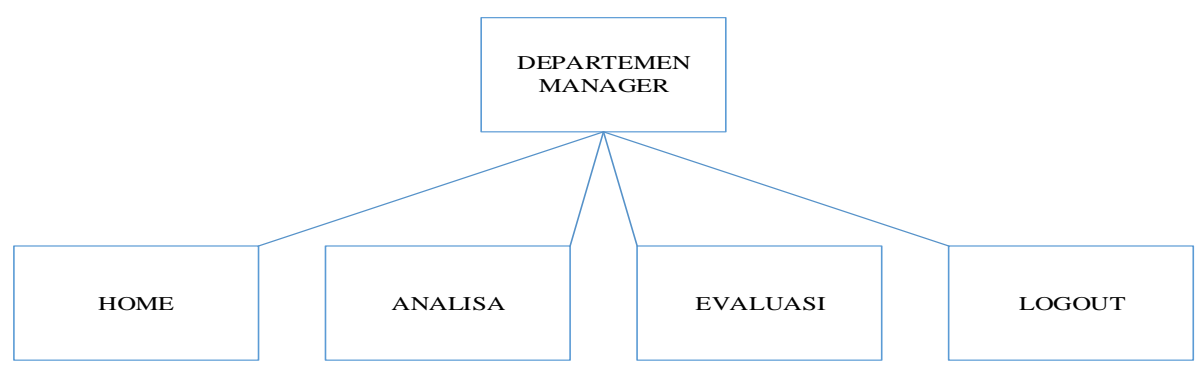

Gambar 12 Struktur Tampilan Menu Departemen Manager

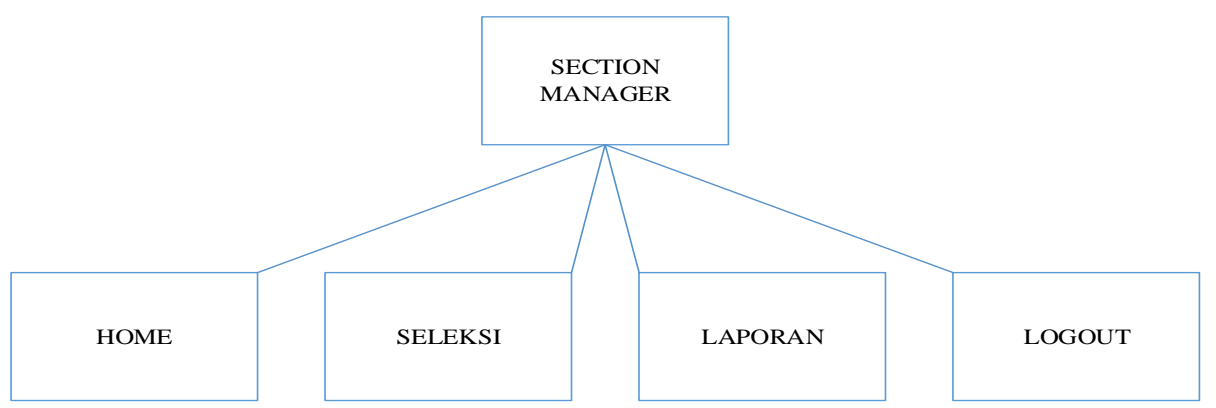

Gambar 13 Struktur Tampilan Menu Section Manager

\section{KESIMPULAN}

1. Penggunaa metode Simple Additive Weighting (SAW) dalam proses pengambilan keputusan pengangkatan karyawan baru di PT. Ultra Prima Plast memberikan kemudahan dalam melakukan penilaian secara lebih tepat dan cepat karena didasarkan pada nilai kriteria dan bobot preferensi yang sudah ditentukan.

2. Rancangan aplikasi Sistem Pendukung Keputusan dapat menyimpan data penilaian kinerja calon karyawan dengan aman dan terhindar dari kemungkinan kehilangan, serta proses pencarian data dapat dilakukan dengan mudah dan cepat 


\section{DaftarPustaka}

Berutu, Edianto (2015), Sistem Pendukung Keputusan Pengangkatan Karyawan Tetap Dengan Metode Analiytic Hierarchy Process (AHP) Pada PT. Perkebunan Lembah Bhakti Propinsi NAD KAB. Aceh

Hasibuan, Melayu S.P. (2009), Manajemen Sumber Daya Manusia, Jakarta, PT. Bumi Askara

Hutahaean, Jeperson (2014)Konsep Sistem Informasi, Yogyakarta: Deepublish Jogiyanto,HM (2008), Analisis dan Desain Sistem Informasi, Yogyakarta: Andi

Kusrini(2007),Konsep dan aplikasi sistem pendukung keputusan. Penerbit andi, Yogyakarta

Boone, Louis E. \& David L. Kurtz (2007), Pengantar Bisnis Komputer, Jakarta, Selemba Empat

Hariandja, Marihot Tua Efendi, Drs., M.Si (2002), Manajemen Sumber Daya Manusia, Jakarta PT GramediaWidiasarana Indonesia

Mulyadi (2010), Sistem Akuntansi, Jogyakarta, SalembaEmpat

Nofriansyah, Dicky (2014), Konsep Data Mining VS Sistem Pendukung Keputusan. Yogyakarta: Deepublish

Nugroho, Bunafit (2013), Aplikasi Pemrograman Web Dinamisdengan PHP dan MySQL. Yogyakarta: Gava Media

Rachmawati, Ike Kusdyah, (2012), Manajemen Sumber Daya Manusia, Yogyakarta, Cv Andi Offset.

Shalahuddin, M. dan Rosa A.S (2015), Rekayasa Perangkat Lunak tertrukstur dan berorientasi objek. Bandung: Informatika Bandung

Sutabri, Tata (2012), Analisa Sistem Informasi. Yogyakarta :Andi

Nafisahsyifaun (2008), grafika computer. Yogyakarta : graham ilmu

O’Brien, J. A., \&Marakas, G. M. (2009), Management Information System Ninth Edition.Mc.Graw - Hill. New York 